\title{
EFFECT OF SERVICE QUALITY AND PRICE ON CUSTOMER SATISFACTION
}

\author{
Safirah Ramadhaniati ${ }^{1}$, Evi Susanti ${ }^{2 *}$, Arjuna Wiwaha ${ }^{3}$, Isthi Wahyuning Tyas ${ }^{4}$ \\ STIE Jakarta International College, Indonesia. \\ *Corresponding Author: evi.susanti@jic.ac.id
}

\begin{tabular}{|c|c|}
\hline ARTICLE INFO & ABSTRACT \\
\hline $\begin{array}{l}\text { Article History: } \\
\text { Received: July } 24,2020 \\
\text { Revised: July 28, } 2020 \\
\text { Published Online: August 17, } 2020 \\
\text { Keywords: } \\
\text { Service Quality, Price, Customer } \\
\text { Satisfaction, Forwarding Company, } \\
\text { Service Industry. } \\
\text { How to cite: }\end{array}$ & $\begin{array}{l}\text { The determinants of customer satisfaction are service quality and price } \\
\text { Therefore, this study aimed to determine the effects of service quality and } \\
\text { price on customer satisfaction. This research was conducted at a } \\
\text { Forwarding Company, with a total sample of } 78 \text { respondents. Meanwhile, } \\
\text { the data analysis method used was descriptive and multiple linear } \\
\text { regression using SPSS } 25 \text {. The results showed that service quality and } \\
\text { price has a significant effect on customer satisfaction with a determination } \\
\text { coefficient of } 50 \% \text {. Meanwhile, the remaining } 50 \% \text { is influenced by other } \\
\text { variables, which have been widely studied. However, research in } \\
\text { forwarding service companies is rarely conducted. }\end{array}$ \\
\hline
\end{tabular}

Rahmadhaniati, S., Susanti, E.,

Wiwaha, A., Tyas, I. W. (2020).

Effect of Service Quality and Price on

Customer Satisfaction. International

Journal of Digital Entrepreneurship

and Business (IDEB), 1(1), 1 - 10 .

\section{INTRODUCTION}

Indonesia is a country with high levels of trade, therefore it needs a transportation service company that can efficiently export support commodity. In this case, freight forwarding is very important in exportimport activities, which is a tool or intermediary in shipping goods exported abroad (Kartika, Riyadi, \& Saptianing, 2016). Nevertheless, this process will not run smoothly without cooperation with other parties, such as shipping, trains, trucks, EMKL (Sea Freight Forwarding) companies, and others.

Customer satisfaction is important for companies to gain the trust of consumers, and make them continue to use their services (Merek, 2018). This can be formed by offering good and competitive services that are well received in the community (Susanti, 2018; Nurlia, 2019). This is in accordance with Lily and Yurike (2015), and Scarlet (2013) identifying the elements which provide satisfaction to customers are the speed of service and the behavior of the staff.

Meanwhile, this satisfaction for the provided services can be measured by the consumers' feedback. Therefore, a service is considered to be satisfying when it fulfills their needs and expectations (Hadiyati, 2019). Satisfaction or dissatisfaction occurs when the customer evaluates expectations with the performance or results received. Previous studies showed that the determinants of customer satisfaction are service quality and the price. (Sanjaya \& Martono, 2012).

Furthermore, service quality focuses on the fulfillment of needs, desires, as well as the accuracy of delivery to balance customer expectations. The quality starts from their needs and ends on their perception. Therefore, the excellence of service quality is expected to attract the consumers to purchase the offered products (Hosang \& Tumbel, 2016). 
To facilitate purchase, the services provided should be in the form of knowledge transferred to the product, corporate responsibility, service timeline assurance, comfort, and empathy towards customers. This is because these components are imprtant determinant in achieving their satisfaction (Susanti, Sule, \& Sutisna, 2015; Lily \& Yurike, 2015). Also, the better the quality of service provided to customers, the more their satisfaction (Sembiring \& Andriani, 2014). Therefore, to build a long-term relationship, the company needs to provide good quality services (Freeman, 2013).

Besides quality, there are other factors that can satisfy customers such as the price of the product (Kristanto, 2011). This is one of the marketing mix elements that require careful consideration. Also, price is the value of a product or service which has aspects that are clearly visible to buyers (Sasmita, Arifin, \& Sunarti, 2013). Therefore, to fulfill customer satisfaction, companies need to provide affordable prices and good quality services (Roring, Oroh, \& Gulla, 2015). Many studies have analyzed the service quality on satisfaction (Scarlet, 2013) in the field of freight services. Meanwhile, prices on satisfaction have been studied by (Natasja Hosang, Tumbel, \& Moniharapon, 2016). Also, service quality and prices effects on satisfaction were studied by (Kristanto, 2011) in the field of food service at One Eighteenth cafe. From the studies above, it can be seen that research on the effects of service quality and price on customer satisfaction in forwarding services is still limited.

According to Kemaev (2017), business companies strive to create customer satisfaction. Also, with the development of freight forwarding and logistics, large or small scale manufacturing companies need their services as a means to transport goods from one place to the other (Rezki, 2019). Furthermore, freight forwarding services are needed to simplify the process of shipping goods using containers via air, land, and sea means.

Service quality is one of the factors that influence customer satisfaction. Therefore, when they are satisfied, they will definitely patronize again (Mardikawati \& Farida, 2013). This will in turn have a positive impact on increasing the company's profits.

In addition to profits, a positive impact for service companies is the satisfaction perceived by users, because the products are intangible (Gürbilek, 2013). Therefore, the industry concentrates on actions that can be felt by, and the goods are attached to the perceived benefits.

\section{LITRATURE REVIEW}

\section{Service Quality}

In principle, service quality focuses on fulfilling the needs and desires of customers, as well as the accuracy to balance their expectations. (Aliansyah \& Hafasnuddin, 2012). In fact, it is seen as one of the components that needs to be realized because it can potentially attract new customers, and can reduce the possibility of losing old clients (Thorik G, 2003).

A high service quality will have a positive impact on customer satisfaction. Therefore, when they don't get the expected quality, their trust will be compromised, which will affect their level of satisfaction, and ultimately make them switch to other service providers (Malik, Ghafoor, \& Iqbal, 2012).

In relation to personal contacts that are very important in determining quality, every company needs service excellence, which is an attitude or the way they satisfactorily serve their customers (Tyas \& Setiawan, 2012).

Furthermore, service means knowing, understanding, and feeling, therefore the delivery will reach the consumers and ultimately strengthen its position in their mind (Winahyuningsih, 2010). Services are activities or benefits that can be provided by one party to another which are basically intangible (Arifin, 2011). Meanwhile, the service itself is an economic process offered by a party in the form of activities 
that bring the desired results of the buyer.

In principle, quality focuses on fulfilling the needs and desires of customers, as well as the accuracy to balance their expectations. Therefore, it can be defined as a comparison between perceived (perception) and expected service (Apriyani, 2013).

Lily and Yurike (2015) defined quality as a measure of how good the level of service provided is able to meet customers' expectation. According to Scarlet (2013), it is the excellence level expected to fulfill users' desires.

\section{Price}

Price plays a strategic role in marketing, therefore when it is too expensive, the relevant product will not reach target markets. Conversely, when it is too cheap, it will be difficult to make profit, and some customers will doubt the quality of the product (Tjiptono, 2015).

Companies can use different means to achieve customer satisfaction, for example by considering the price factor. In general, consumers tend to choose companies that offer their products at relatively low prices (Amanah, 2013).

Price is an important factor when choosing a product or service (Nazaruddin, 2019). This statement is supported by a research which showed that price has a relationship with satisfaction. When customers believe that the price of a product is reasonable, they tend to make more purchase. Conversely, when they perceive the price is high, they will purchase less, and may switch to other service providers (Nofrianda, 2019).

Reasonable pricing, which is one of the marketing strategies that determine transaction between sellers and buyers is important in maintaining purchase (Batubara \& Hidayat, 2016). Hence, setting a relatively high price will lead to decline in sales, however when it is too low, profits will be reduced (Tjiptono, 2015).

Companies that are able to set the right price will certainly obtain satisfying marketing results (Sagala, 2016). Also, setting reasonable pricing play an important role for customers in making purchases. In purchasing decisions, they expect the quality and performance of a product or service to be optimal.

Price is the amount of money as a medium of exchange for obtaining a product or service. It is a factor that determines the value of a product in the minds of consumers (Roring et al., 2015). Therefore, it is the amount of money (plus some products) needed to get a combination of products and services (Amanah, 2013).

In a narrow sense, it is the money billed for a product or service, while in the broad sense, it is the value exchanged by consumers for the benefit of owning or using a product or service. According to the definition above, the policy regarding price is only temporary (Heriyanto, 2015). According to Wiyadi (2017), its role according to in the economy is to determine the level of wages, profits, interest, and rent. Therefore, prices for consumers are used as a basis of decisions in purchasing a product or service. For the company, the price set can be its revenue.

\section{Customer Satisfaction}

Due to increased competition, service providers need to preserve their customers by providing the best product. In an organization that engage in services, maintaining employee performance is one of the ways to fulfill satisfaction (Indrawati, 2013). Therefore, customers will be satisfied as long as their expectations are met, and even feel very happy when they are exceeded.

When customers are satisfied, it will establish a harmonious relationship between producers and 
consumers, create a good basis for repeat purchases and form recommendations that benefits the company (Panjaitan \& Yuliati, 2016). Therefore, satisfaction becomes an important parameter that is necessary for a business sustainability (Aryani, 2010).

Oktarini (2019) stated that satisfaction is a post-purchase evaluation, where the perception on the performance of alternative products or services fulfill or exceed expectations before purchase. Therefore, when perceptions of performance cannot fulfill expectations, dissatisfaction occurs.

According to Khasanah and Pertiwi (2010), consumer satisfaction is the feeling of pleasure or disappointment regarding an expectation. Therefore, when the product's performance is not in accordance with its expectations after consumption, the consumer will feel dissatisfied and disappointed. However, when the performance meets expectations, they will feel excited to use the product or service again.

Basically, satisfaction is the level of consumer feeling after comparing the perceived service with the expected performance. This means that the level of satisfaction is a function of the difference between expectations and performance. When this is below the expected level, the consumers will be disappointed. However, when it meets their expectation, they will feel satisfied. Therefore, the satisfying service is part of a company's future (Kaihatu \& Siwalankerto, 2008).

\section{Hypothesis Development: \\ Service Quality with Customer Satisfaction}

Service quality is a factor that determines the success level of a company in providing for consumers. It is also a corporate strategy to defend and achieve success in the face of competition. When the company does something that is not in accordance with customer expectations, it means a good quality service is not provided. The explanation above showed that quality is needed in shaping customer satisfaction, because the better the experience, the more they are pleased.

This is in accordance with Kemaev (2017), and Susanti (2018), which showed that service quality has a significant effect. Therefore, the better the service quality, the higher the satisfaction level. Based on the theory and description, the following hypothesis can be formulated:

\section{H1 : Service Quality has a partial effect on Customer Satisfaction in Forwarding Freight Express.}

\section{Effect of Price on Customer Satisfaction}

Price is the amount of money (plus a few items) needed to get a combination of goods and services. It is one of the marketing mix elements that generates income, while the others produce costs. Furthermore, it plays a role in influencing post purchase satisfaction and the desire to use again. This happens to sales because services can only be felt. Therefore, customers are required to depend on price cues. In some cases, price may be the dominant influence of satisfaction and the desire to reuse.

This is in accordance with Lily and Yurike (2015), which showed that price has a significant effect on satisfaction.

\section{H2 : Price has a partial effect on customer satisfaction}

\section{Effect of Service Quality and Price on Customer Satisfaction}

As long as the customer is satisfied with the service quality and the price charged, there is a high possibility that they will purchase again. Also, satisfied customers will tend to provide good feedback on products or services, and even recommend them to others. However, when the quality of the product or service is poor, and the price is high, there will be dissatisfaction. The effect of this situation is that disappointed customers will tell others, which will have a negative impact on the company. Therefore, potential customers may tend to choose competitors services which they consider to be more reliable in meeting their demand. 
This is in accordance with Lily and Yurike (2015), and Malik et al. (2012) which showed that service quality and price have an effect on customer satisfaction.

\section{H3 : Service Quality and Price have a simultaneous effect on Customer Satisfaction}

$\mathrm{H}_{3}$

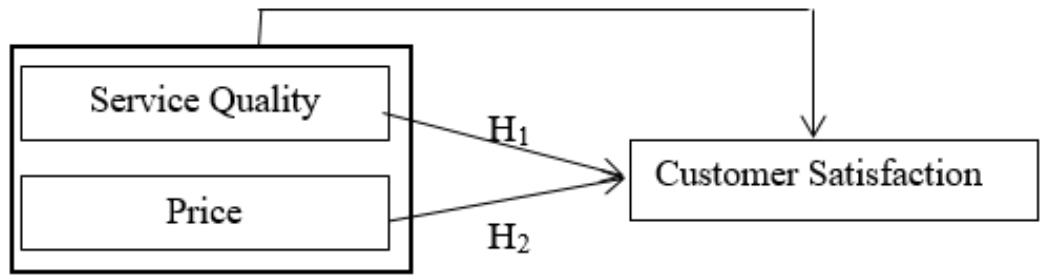

Figure 1: Research Model

\section{METHOD}

This study was conducted at a forwarding company in Jakarta with a sample size of 100 respondents who are consumers of the services. Also, the determination of total sample was according to the Isaac and Michael table, with a degree of error or $\alpha$ of $5 \%$, namely 78 customers.

The measurement of each variable used 5 points on a Likert scale, from 1 (strongly disagree) to 5 (strongly agree). Furthermore, the measurement of service quality used 5 dimensions from (Parasuraman, Berry, \& Zeithaml, 1991). In addition, price and customer satisfaction measurement used dimensions from (Kemaev, 2017).

Table 1: Operationalization of Variables

\begin{tabular}{|c|c|c|c|c|c|}
\hline No. & Variable & Definition & $\begin{array}{l}\text { Dimensions / } \\
\text { Indicators }\end{array}$ & $\begin{array}{l}\text { Authors with } \\
\text { Resources }\end{array}$ & Scale \\
\hline 1 & $\begin{array}{l}\text { Service } \\
\text { quality }\left(\mathrm{X}_{1}\right)\end{array}$ & $\begin{array}{l}\text { Service quality is an } \\
\text { expected level of } \\
\text { excellence, and it is } \\
\text { related to control } \\
\text { measures needed to } \\
\text { fulfill consumers } \\
\text { expectations. }\end{array}$ & $\begin{array}{l}\text { 1. Reliability } \\
\text { 2. Responsiveness } \\
\text { 3. Empathy } \\
\text { 4. Assurance } \\
\text { 5. Tangible }\end{array}$ & $\begin{array}{l}\text { Parasuraman et } \\
\text { al. (1991) }\end{array}$ & Likert \\
\hline 2 & Price $\left(\mathrm{X}_{2}\right)$ & $\begin{array}{l}\text { Price is the amount of } \\
\text { money as a medium } \\
\text { of exchange to obtain } \\
\text { a product or service. } \\
\text { It can also be said to } \\
\text { determine the value } \\
\text { of a product in the } \\
\text { consumers' minds. }\end{array}$ & $\begin{array}{l}\text { 1. Price affordability } \\
\text { 2. Price } \\
\text { competitiveness } \\
\text { 3. Price and quality } \\
\text { suitability }\end{array}$ & Kemaev (2017) & Likert \\
\hline 3 & $\begin{array}{l}\text { Customer } \\
\text { Satisfaction } \\
\text { (Y) }\end{array}$ & $\begin{array}{l}\text { Consumer } \\
\text { satisfaction is a } \\
\text { feeling of pleasure or } \\
\text { disappointment } \\
\text { regarding the } \\
\text { performance or } \\
\text { results of a product. }\end{array}$ & $\begin{array}{l}\text { 1. Suitability of service } \\
\text { with expectations } \\
\text { 2. Suitability of service } \\
\text { with the tariff paid } \\
\text { 3.Customer satisfaction } \\
\text { for the services offered }\end{array}$ & Kemaev (2017) & Likert \\
\hline
\end{tabular}

The data analysis technique used was the classical assumption test and the regression method, using statistical hypothesis testing. It aimed to measure the effects of service quality and price on customer satisfaction. To measure these variables, a Likert scale questionnaire was used. 
The validity test criteria used degrees of freedom (n-2) and $\alpha=0.05$. Therefore, when $r_{\text {count }}>r_{\text {table, }}$ it means that the item is valid. Meanwhile, the validity test used is the product moment correlation test. The value of $r_{\text {table }}$ used based on the level of confidence at $\alpha=0.05$ is 0.361 with 30 respondents. Therefore, the results of the correlation coefficients from each indicator are all greater than $r$ table of 0.361. It was then concluded that all research instruments were valid (Nofrianda, 2019). Meanwhile, data were processed using SPSS software version 25.

After conducting validity test, the reliability test was performed for the three variables. A measuring instrument is declared reliable when the Cronbach Alpha value is greater than 0.6, and the item is deleted when the value is smaller than 0.6. Therefore, service quality, price, and customer satisfaction variables have been tested and the results showed that each statement on the three variables are valid and reliable (Maria \& Anshori, 2013).

Table 2: Reliability Tests of the Variables

\begin{tabular}{|l|c|c|}
\hline Reliability Statistics & Cronbach's Alpha & N of Items \\
\hline Variable X1 (Service Quality) & .790 & 11 \\
\hline Variable X2 (Price) & .859 & 4 \\
\hline Variable Y (Customer Satisfaction) & .863 & 4 \\
\hline
\end{tabular}

Source: Primary data, SPSS 25, 2020

\section{RESULT AND DISCUSSION}

The respondent data based on gender showed $24.4 \%$ of Male and $75.6 \%$ of Female. Most of them were 17-30 years old with the largest occupations as private employees.

The simple regression equation for service quality and customer satisfaction was $\hat{Y}=9.345+0.065 . X_{1}$. Also, price and customer satisfaction was $\hat{Y}=4.684+0.602 . X_{1}$. Meanwhile, the multiple regression equation was $\hat{\mathrm{Y}}=3.890+0.025 \mathrm{X}_{1}+0.586 \mathrm{X}_{2}$.

The correlation coefficient of service quality to customer satisfaction was $\mathrm{R}=0.232$, which means there is a positive and strong relationship. The coefficient of price to customer satisfaction was $\mathrm{R}=0.701$, which means there is also a strong and positive relationship. In addition, the multiple correlation coefficient was $\mathrm{R}=0.707$, which means there is a positive relationship.

Analysis of the coefficient of determination $\left(\mathrm{R}^{2}\right)$ involves measuring the model's ability to explain the variation of the dependent variable. Meanwhile, the coefficient of determination for service quality to customer satisfaction was $5.4 \%$, and price to customer satisfaction was $49.2 \%$. Simultaneously, the coefficient of determination for service quality and price to customer satisfaction was $50 \%$.

The $t$ statistical test showed the partial effect of independent variables on dependent type.

Table 3: T Statistical Test of Service Quality $\left(\mathrm{X}_{1}\right)$ on Customer Satisfaction (Y)

\begin{tabular}{ll|l|l|l|l|l|l}
\hline & \multicolumn{2}{l}{$\begin{array}{l}\text { Unstandardized } \\
\text { Coefficients }\end{array}$} & $\begin{array}{l}\text { Standardized } \\
\text { Coefficients }\end{array}$ & & & \multicolumn{2}{c}{ Collinearity Statistics } \\
Model & B & Std. Error & Beta & t & Sig. & Tolerance & VIF \\
\hline 1 (Constant) & 9.345 & 1.233 & & 7.581 & .000 & & \\
\hline Service Quality & .065 & .031 & .232 & 2.077 & .041 & 1.000 & 1.000 \\
\hline
\end{tabular}

Source: Primary Data, 2020

The $t_{\text {count }}$ value was 2.077 and $t_{\text {table value was }} 1.99167(\alpha=0.05)$. This means the hypothesis is accepted because there is an influence of service quality on customer satisfaction. 
Table 4: T Statistical Test of Price $\left(\mathrm{X}_{2}\right)$ on Customer Satisfaction $(Y)$ Coefficients $^{\mathrm{a}}$

\begin{tabular}{|c|c|c|c|c|c|c|c|}
\hline \multirow[b]{2}{*}{ Model } & \multicolumn{2}{|c|}{$\begin{array}{l}\text { Unstandardized } \\
\text { Coefficients }\end{array}$} & \multirow{2}{*}{$\begin{array}{l}\text { Standardized } \\
\text { Coefficients } \\
\text { Beta }\end{array}$} & \multirow[b]{2}{*}{ t } & \multirow[b]{2}{*}{ Sig. } & \multicolumn{2}{|c|}{ Collinearity Statistics } \\
\hline & B & Std. Error & & & & Tolerance & VIF \\
\hline 1 (Constant) & 4.684 & .851 & & 5.504 & .000 & & \\
\hline Price & .602 & .070 & .701 & 8.575 & .000 & 1.000 & 1.000 \\
\hline
\end{tabular}

Source: Primary Data, 2020

The $t_{\text {count }}$ value was 8.575 and the $t_{\text {table }}$ value was $1.99167(\alpha=0.05)$. This means the hypothesis is accepted because there is an influence of service quality on customer satisfaction.

F statistical or simultaneous significance test was conducted to show whether all dependent or independent variables in the model have a simultaneous effect.

Table 5: $\mathrm{F}_{\text {Test }}$ Results $-\mathrm{ANOVA}^{\mathrm{a}}$

\begin{tabular}{|c|c|c|c|c|c|}
\hline Model & Sum of Squares & Df & Mean Square & $\mathbf{F}$ & Sig. \\
\hline 1 Regression & 126.246 & 2 & 63.123 & 37.433 & $.000^{\mathrm{b}}$ \\
\hline Residual & 126.471 & 75 & 1.686 & & \\
\hline Total & 252.718 & 77 & & & \\
\hline
\end{tabular}

a. Dependent Variable: Customer Satisfaction

b. Predictors: (Constant), Price, Service Quality

Source: Primary Data, 2020

From the ANOVA test or $F$ test, the value of $F_{\text {count }}$ was 37.433 with a probability of 0.000 . Therefore, because it is much smaller than 0.05 , the regression model can be used to predict service quality. In addition, it can be said that quality and price simultaneously affect customer satisfaction

The research results showed that service quality has a positive and significant effect on satisfaction. This means that the better the level of service provided, the higher the customer satisfaction. These results support Dewi et al. (2016); Oktarini (2019), Merek, (2018) which showed that service quality and price has a significant effect.

Furthermore, price has a positive and significant effect on customer satisfaction. This means that the more affordable the service, the higher their satisfaction and purchasing power. These results support Lily \& Yurike (2015), Amanah (2013), and Kristanto (2011) which showed that price has a significant effect on customer satisfaction.

Also, both service quality and price have a positive and significant effect on customer satisfaction. This means that the better the quality and affordability, the higher the satisfaction. These results support Kemaev (2017), Gofur (2019), and Prasetio (2012) which showed that price has a significant effect on customer satisfaction.

\section{CONCLUSION}

The research results showed that service quality and price had a positive and significant effect on customer satisfaction. This means that all the hypotheses are accepted. Therefore, the practical implication on the forwarding industry is considering prices that are directly proportional to the services provided. This can increase satisfaction by providing guarantees for goods delivered. In fact, it can increase opportunities for the business. This research is still limited to the studied variables, which are quality, price, and customer satisfaction in forwarding service companies. Therefore, further studies need to include other variables that can increase satisfaction, such as purchasing decisions or customer retention with a larger sample size. 


\section{REFERENCES}

Amanah, D. (2013). Pengaruh Harga dan Kualitas Produk Terhadap Kepuasan Konsumen pada Majestyk Bakery. Journal of Chemical Information and Modeling, 53(9), 1689-1699. https://doi.org/10.1017/CBO9781107415324.004

Apriyani, Y. (2013). Pengaruh Brand Image ,Harga dan Kualitas Pelayanan Terhadap Keputusan Pembelian Ulang Pizza Hut di Kota Padang. Manajemen, 2(1), 1-10.

Aryani, D. W. I. (2010). Pengaruh Kualitas Layanan terhadap Kepuasan Pelanggan dalam Membentuk Loyalitas Pelanggan. 17, 114-126.

Batubara, A., \& Hidayat, R. (2016). Pengaruh Penetapan Harga dan Promosi Terhadap Tingkat Penjualan Tiket. Jurnal Akuntansi, 4(1), 33-46.

Dewi Sanjaya, I., \& Martono, S. (2012). Management Analysis Journal. 1(2), 120-128.

Gofur, A. (2019). Pengaruh Kualitas Pelayanan dan Harga Terhadap Kepuasan Pelanggan. Jurnal Riset Manajemen dan Bisnis (JRMB) Fakultas Ekonomi UNIAT, 4(1), 37-44. https://doi.org/10.36226/jrmb.v4i1.240

Gürbilek, N. (2013). Kualitas Pelayanan. Journal of Chemical Information and Modeling, 53(9), 16891699. https://doi.org/10.1017/CBO9781107415324.004

Hadiyati, E. (2019). Analisis Kualitas Pelayanan dan Pengaruhnya terhadap Loyalitas Pelanggan. Journal of Chemical Information and Modeling, 53(9), 1689-1699. https://doi.org/10.1017/CBO9781107415324.004

Heriyanto, I. (2015). Analisis Pengaruh Produk, Harga, Distribusi Dan Promosi Terhadap Keputusan Pembelian serta Implikasinya pada Kepuasan Pelanggan. Jurnal Ekonomi, Bisnis \& Entrepreneurship, 9(2), 80-101.

Indrawati, A. D. (2013). Pengaruh Kepuasan Kerja terhadap Kinerja Karyawan dan Kepuasan Pelanggan pada Rumah Sakit Swasta. 135-142.

Jessica Ordelia Kristanto. (2011). Terhadap Kepuasan Pelanggan Di Cafe One Eighteenth Jessica Ordelia Kristanto. 9.

Kaihatu, T. S., \& Siwalankerto, J. (2008). Analisa Kesenjangan Kualitas Pelayanan dan Kepuasan Konsumen Pengunjung Plaza Tunjungan Surabaya. Jurnal Manajemen dan Wirausaha, 10(1), 6683. https://doi.org/10.9744/jmk.10.1.pp.66-83

Kartika, Riyadi, Saptianing. (2016). Pengaruh Kualitas Pelayanan Jasa Forwarding terhadap Kepuasan. Society, Polines, ISSN 1411-4321, 55-66

Kemaev, E. N. (2017). Pengaruh Kualitas Layanan dan Harga terhadap Kepuasan Pelanggan Jasa Transportasi Ojek Online (Studi Pada Konsumen Gojek di Surabaya). Bulletin of the Kalmyk Institute for Humanities of the Russian Academy of Sciences, 33(5), 82-92. https://doi.org/10.22162/2075-7794-2017-33-5-82-92

Khasanah, I., \& Pertiwi, O. D. (2010). Kualitas Layanan terhadap Kepuasan Konsumen RS St. Elisabeth Semarang. Jurnal Khasanah Pertiwi, 12(2), 117-124.

Lee, S., Hahn, C., Rhee, M., Oh, J. E., Song, J., Chen, Y., Fallis, A. (2012). Pengaruh Kualitas Pelayanan dan Harga terhadap Nilai Pelanggan dan terhadap Kepuasan Penggunaan Jasa Service. Journal of Chemical Information and Modeling, 53(9), 1689-1699. https://doi.org/10.1017/CBO9781107415324.004

Lily, H., \& Yurike, V. (2015). Maskapai Penerbangan Tiger Air Mandala. E-Journal WIDYA Ekonomika, 1(2338-7807), 11.

Malik, M. E., Ghafoor, M. M., \& Iqbal, H. K. (2012). Impact of brand Image, Service Quality and Price on Customer Satisfaction in Pakistan Telecommunication Sector. International Journal of Business and Social Science, 3(23), 123-130.

Mardikawati, W., \& Farida, N. (2013). Loyalitas Pelanggan , melalui Kepuasan Pelanggan pada Pelanggan Bus Efisiensi (Studi PO Efisiensi Jurusan Yogyakarta-Cilacap). Jurnal Administrasi Bisnis, 2(1), 64-75.

Maria, M., \& Mohamad Yusak Anshori. (2013). Pengaruh Kualitas Produk dan Kualitas Layanan terhadap Kepuasan Konusmen King Cake. Manajemen Teori dan Terapan, (1), 50-51.

Merek, P. C., (2018). Kualitas Layanan, terhadap Kepuasan Pelanggan Go-Ride. Fakultas Administrasi, Universitas Brawijaya, 61(2), 118-126. 
Mulyadi, H., \& Saktiawati, D. (2008). Pengaruh Brand Personality terhadap Loyalitas Pelanggan Sampo Sunslik, Strategik Jurnal Pendidikan Manajemen Bisnis, Volume 7 (13), 21-32.

Natasja Hosang, Altje Tumbel, S. M. (2016). Analisis Pengaruh Kualitas Pelayanan dan Harga Terhadap Kepuasan Pasien ( Studi Kasus pada Rumah Sakit Siloam Manado ) Jurnal Berkala Ilmiah Efisiensi, 16(01), 159-171.

Nazaruddin. (2019). Pembelian Air Minum Dalam Kemasan (AMDK) Merek Aicos Produksi PT. . Bumi Sarimas Indonesia. 1-9.

Nofrianda, H. (2019). Analisis Pengaruh Kualitas Produk, Kualitas Layanan dan Harga terhadap Kepuasan Konsumen (Studi Kasus Pada Konsumen Industri/ Toko Bakery di Kota Bengkulu). Managament Insight: Jurnal Ilmiah Manajemen, 13(1), 71-85. https://doi.org/10.33369/insight.13.1.71-85

Nurlia, T. (2019). Pengaruh Kualitas Pelayanan, Harga dan Citra Merek terhadap Kepuasan Mahasiswa. Jurnal Lentera Bisnis, 8(2), 104. https://doi.org/10.34127/jrlab.v8i2.289

Oktarini, R. (2019). Pengaruh Kualitas Produk, Kualitas Pelayanan, dan Harga. Ilmiah Ilmu Sekretari/Administrasi Perkantoran, 6(2), 1-10.

Panca Winahyuningsih. (2010). Pengaruh Kepercayaan dan Kualitas Pelayanan terhadap Kepuasan Konsumen Pada Hotel Griptha Kudus. ISSN 1979-6889 Pengaruh, 1-17.

Panjaitan \& Yuliati, (2016), Pengaruh Kualitas Pelayanan terhadap Kepuasan Pelanggan pada JNE Cabang Bandung, Jurnal Manajemen, 11(2), 1-25.

Parasuraman, A., Berry, L. L., \& Zeithaml, V. A. (1991). Perceived Service Quality as a CustomerBased Performance Measure: An Empirical Examination of Organizational Barriers using An Extended Service Quality Model. Human Resource Management, 30(3), 335-364. https://doi.org/10.1002/hrm.3930300304

Prasetio, A. (2012). Kualitas Pelayanan dan Harga terhadap Kepuasan Pelanggan. Management Analysis Journal. 1(2), 120-128.

Rezki, M. (2019). Pengaruh Kualitas Layanan dan Harga terhadap Kepuasan Pelanggan Jasa Transportasi Ojek. Jurnal Pendidikan Tata Niaga (JPTN), 4(3), 50-57.

Roring, F., Oroh, S., \& Gulla, R. (2015). Analisis Harga, Promosi, dan Kualitas Pelayanan terhadap Kepuasan Konsumen Pada Hotel Manado Grace Inn. Jurnal Riset Ekonomi, Manajemen, Bisnis dan Akuntansi, 3(1), 1313-1322.

Sagala, R. (2016). Manajemen Pemasaran. Landasanteori.Com, (2012), 1-17.

Samsul Arifin. (2011). Pengaruh Kepercayaan, Fasilitas dan Kualitas Pelayanan terhadap Kepuasan Konsumen pada Hotel Jepara Indah, 8, 67-78.

Sasmita, R., Arifin, Z., \& Sunarti. (2013). Pengaruh Kualitas Pelayanan terhadap Kepuasan Nasabah (Studi pada Nasabah PT. Asuransi Jiwasraya ( Persero ) Malang Regional Office). 25(1), 1-6.

Scarlet, D. (2013). Pengaruh Kualitas Pelyanan dan Tarif terhadap Loyalitas Pelanggan dengan Kepuasan Pelanggan DHL. Journal of Chemical Information and Modeling, 53(9), 1689-1699. https://doi.org/10.1017/CBO9781107415324.004

Sembiring, S. I. J., \& Andriani, K. (2014). Kepuasan Pelanggan dalam Membentuk Loyalitas Pelanggan (Studi pada Pelanggan McDonald 's MT . Haryono Malang). Jurnal Administrasi Bisnis (JAB)|Vol., 15(1), 1-10.

Susanti, E. (2018). Kualitas Layanan Internal yang Memengaruhi Kepuasan Nasabah dengan Menggunakan Kualitas Layanan Eksternal sebagai Variabel Mediasi. Jurnal Manajemen dan Pemasaran Jasa, 11(1), 95. https://doi.org/10.25105/jmpj.v11i1.2099

Susanti, E., Sule, E. T., \& Sutisna, H. (2015). The Impact of Internal and External Service Quality (A Case Study among Lecturers and Students). Mediterranean Journal of Social Sciences, 6(5), 77-83. https://doi.org/10.5901/mjss.2015.v6n5s5p77

Teuku Aliansyah, Hafasnuddin, S. (2012). Pengaruh Dimensi Kualitas Pelayanan terhadap Kepuasan Nasabah Bank Aceh Syariah Cabang Banda Aceh. Jurnal Manajemen Pascasarjana Universitas Syiah Kuala, 1(1), 32-39.

Thorik G. (2003). Pengaruh Kualitas Pelayanan pada Bank Syariah. Standar Oprasional Prosedur Pramusaji untuk Meningkatkan Kepuasan Tamu di Saffron Restaurant, (7), 1-16.

Tjiptono, F. (2015). Strategi Pemasaran. Edisi III, Yogyakarta. 
Tyas, R. R., \& Setiawan, A. (2012). Pengaruh Lokasi dan Kualitas Pelayanan terhadap Keputusan Nasabah untuk Menabung di BMT Sumber Mulia Tuntang. Muqtasid: Jurnal Ekonomi dan Perbankan Syariah, 3(2), 277. https://doi.org/10.18326/muqtasid.v3i2.277-297

Wiyadi \& Setyowati, E. (2016). Pengaruh Pelayanan, Harga dan Citra Merek terhadap Loyalitas Pelanggan dengan Kepuasan Pelanggan sebagai Variabel Pemediasi. Jurnal Ekonomi Manajemen Sumber Daya, Vol 12 (2), 102-112 